\title{
The Stagnation OF HOUSEHOLD CONSUMPTION IN JAPAN
}

\author{
CHARLES YUJI HORIOKA
}

\author{
CESIFO WORKING PAPER NO. 1133 \\ CATEGORY 6: MONETARy POLICY AND INTERNATIONAL FinANCE \\ FEBRUARY 2004
}

Presented at Venice Summer Institute, Workshop on Economic Stagnation in Japan July 2003 


\title{
THE StAgnation OF HouseHOld CONSUMPTION IN JAPAN
}

\begin{abstract}
In this paper, I consider the extent to which the stagnation of household consumption is responsible for the decade-long recession in Japan during the 1990s and early 2000s and the reasons for the stagnation of household consumption during this period and find that the stagnation of private investment (and inventory investment) rather than that of household consumption was the major cause of the decade-long recession, that household consumption was nonetheless relatively stagnant during this decade, and that the stagnation of household consumption was due primarily to the stagnation of household disposable income, the decline in household wealth (which in turn was due primarily to the collapse of land and equity prices), and to a lesser extent, increased uncertainty about the future (especially about old age in general and old-age pensions in particular), the deterioration of future prospects, and deflationary expectations concerning consumer prices.
\end{abstract}

JEL Classification: E21, E32.

\author{
Charles Yuji Horioka \\ Institute of Social and Economic Research \\ Osaka University \\ 6-1, Mihogaoka, Ibaraki \\ Osaka 567-0047 \\ Japan \\ horioka@iser.osaka-u.ac.jp
}

I am grateful to Sheldon Garon, Takeo Hoshi, Michael Hutchison, Akira Nagae, Shinpei Sano, Shizuka Sekita, Dong Shen, Dariusz Stanko, Midori Wakabayashi, Junmin Wan, Frank Westermann, Keiko Yoshida, Yanfei Zhou, participants of the CESifo Venice Summer Institute (VSI) Workshop on "Economic Stagnation in Japan," which was held July 25-26, 2003, in Venice, Italy, and especially Bernadette Andreosso-O'Callaghan (the designated discussant) and Keunkwan Ryu for their helpful and insightful comments. The author is also grateful to the Ministry of Education, Culture, Sports, Science and Technology of the Japanese Government for Grant-in-Aid for Scientific Research number 12124207, which supported this research. 


\section{Introduction}

Japan's economy has been in recession more or less continuously for more than a decade (Japan's so-called “Lost Decade"), and Japan's growth rate during this period has been the lowest among the major industrialized countries of the world. During the 1995-2002 period, for example, the annual growth rate of Japan's real GDP averaged only $1.2 \%$, which is lower than all of the other G7 countries - Canada (3.4\%), the United States (3.2\%), the United Kingdom (2.7\%), France (2.3\%), Italy (1.8\%), and Germany (1.4\%)--as well as the Euro area average (2.2\%) and less than half of all of the other larger OECD countries-Korea (5.3\%), Australia (3.8\%), Spain (3.3\%), the Netherlands (2.9\%), and Mexico (2.6\%)--as well as the OECD-wide average (2.7\%).

In this paper, I consider the extent to which the stagnation of household consumption is responsible for the decade-long recession in Japan during the 1990s and early 2000s and the reasons for the stagnation of household consumption during this period. The paper is organized as follows: section 2 considers the first issue, section 3 considers the second issue, and section 4 is a brief concluding section.

To preview the main findings of this paper, I find that the stagnation of private investment (and inventory investment) rather than that of household consumption was the major cause of the decade-long recession in Japan during the 1990s and early 2000s, that household consumption was nonetheless relatively stagnant during this decade, and that the stagnation of household consumption was due primarily to the stagnation of household disposable income, the decline in household wealth (which in turn was due primarily to the collapse of land and equity prices), and to a lesser extent, increased uncertainty about the future (especially about old age in general and old-age pensions in particular), the deterioration of future prospects, and deflationary expectations concerning consumer prices.

\section{The Contribution of the Stagnation of Household Consumption to the Decade-Long}

\section{Recession}

In this section, I consider the extent to which the stagnation of household consumption is responsible for the decade-long recession of the 1990s and early 2000s. I first consider the 
period of analysis as a whole (1991-2002) and then divide this period into two subperiods (1991-1997 and 1997-2002) because GDP growth was considerably higher during the first subperiod than it was during the second subperiod (1.58\% vs. $0.36 \%)$.

Table 1 shows the average annual real growth rate of gross domestic product (GDP) and the various components thereof during the 1991-2002 period as a whole, the 1991-1997 subperiod, and the 1997-2002 subperiod, and as can be seen from this table, the average growth rate of GDP during these three periods was a mere $1.03 \%, 1.58 \%$, and $0.36 \%$, respectively, whereas the average growth rate of household consumption during the same three periods was $1.35 \%, 1.94 \%$, and $0.65 \%$, respectively. Thus, the average growth rate of household consumption was considerably higher than that of GDP in all three periods albeit not high in absolute terms and not nearly as high as the average growth rate of some other components of GDP: the growth rate of the consumption of private non-profit institutions serving households was $4.55 \%, 4.64 \%$, and $4.44 \%$, respectively; that of the net exports of goods and services was $4.55 \%, 3.09 \%$, and $6.32 \%$, respectively; that of government consumption was $3.07 \%, 2.82 \%$, and $3.38 \%$, respectively, during the three periods considered; and that of public fixed investment and inventory investment was $4.00 \%$ and $2.18 \%$, respectively, during the $1991-97$ period). Preliminary figures show that the growth rate of household consumption fell short of that of GDP during each of the first three quarters of 2003, but if this most recent period is ignored, the average growth rate of household consumption exceeded that of GDP, which implies that household consumption did not act as a drag on the economy and in fact raised rather than lowering the growth rate of GDP. ${ }^{1}$

What did act as a drag on the economy were private fixed investment and inventory investment (changes in inventories), both of which showed slower growth than GDP and in fact showed negative growth throughout the 1991-2002 period (with one exception): $-1.19 \%,-0.96 \%$, and $-1.47 \%$, respectively, in the case of private fixed investment, and $-193.06 \%, 2.18 \%$, and $-183.19 \%$, respectively, in the case of inventory investment during the three periods considered. A breakdown of private fixed investment shows that private housing (dwelling) investment declined especially sharply $(-2.58 \%,-0.72 \%$, and $-4.76 \%$, respectively, during the three periods considered), which suggests that it might have been the primary culprit of the decade-long 
recession. Preliminary figures indicate that private housing investment continued to decline in the first two quarters of 2003 but finally began recovering in the third quarter of 2003, indicating that it continued to act as a drag on the Japanese economy until very recently.

Table 2 shows the contribution to real GDP growth of each component thereof during the 1991-2002, 1991-1997, and 1997-2002 periods, and as can be seen from this table, household consumption made by far the largest contribution to real GDP growth during the 1991-2002 and 1991-1997 periods (70.30\% and 64.95\%, respectively) and the second largest contribution (96.70\%) during the 1997-2002 period. If the components of GDP are ranked by their contribution to real GDP during the 1991-2002 period as a whole, government consumption was in second place with a contribution of $44.60 \%, 24.65 \%$, and $143.02 \%$, respectively, net exports of goods and services was in third place with a contribution of $9.20 \%, 3.51 \%$, and $37.24 \%$, respectively, public fixed investment was in fourth place with a contribution of $4.40 \%, 17.26 \%$, and $-59.00 \%$, respectively, and the consumption of private non-profit institutions serving households was in fifth place with a contribution of $4.34 \%, 2.58 \%$, and $13.00 \%$, respectively, during the three time periods considered. Some have claimed that strong export growth prevented the decade-long recession from becoming even worse, but the contribution of net exports to real GDP growth was relatively modest and it ranked only third or fourth. The contributions of private fixed investment $(-25.30 \%,-13.82 \%$, and $-81.94 \%$, respectively) and inventory investment $(-7.54 \%, 0.86 \%$, and $-49.01 \%$, respectively) to real GDP growth were negative in all but one case during the three time periods considered, with the contribution of private fixed investment being especially large in absolute magnitude. A breakdown of private fixed investment shows that private housing investment was responsible for $43.28 \%, 16.28 \%$, and $65.72 \%$, respectively, of the negative contribution of private fixed investment during the three time periods considered, meaning that its impact does not clearly dominate that of private plant and equipment investment, contrary to what I surmised earlier (more on this later).

Some of the foregoing results concerning the average growth rates of each component of GDP and its contribution to real GDP growth are seemingly at odds with one other, but the differences can be explained by the shares of each component in total GDP. For example, 
household consumption made by far the largest contribution to real GDP growth during the 1991-2002 period as a whole as well as during the 1991-1997 subperiod and the second highest contribution to real GDP growth during the 1997-2002 subperiod even though, as noted earlier, the average growth rate of household consumption was much lower than that of some other components of GDP during all three periods considered simply because it is by far the largest component of GDP with a share of 52.6 to $54.5 \%$ (see Table 3). Conversely, the consumption of private non-profit institutions serving households contributed relatively little to real GDP growth during all three periods considered even though it showed the first or second highest growth rate simply because its share of GDP is so small ( 0.8 to $1.2 \%$ or sixth among the seven components of GDP). Similarly, the contribution of the net exports of goods and services to real GDP was only third or fourth highest even though its growth rate was the first or third highest simply because its share of GDP is so small ( 1.7 to $2.5 \%$ or fifth among the seven components of GDP). As another example, inventory investment contributed much less toward holding down real GDP growth during the 1991-2002 period as a whole as well as during the 1997-2002 subperiod even though it declined much more sharply than private fixed investment during these periods simply because its share of GDP is so much smaller (-0.3 to $0.6 \%$ or smallest among the seven components of GDP in the case of inventory investment vs. 19.1 to $24.4 \%$ or second largest among the seven components of GDP in the case of private fixed investment). As a final example, private housing investment did not contribute more to holding down real GDP growth than did private plant and equipment investment (except during the 1997-2002 subperiod) even though its growth rate was much higher (except during the 1991-1997 subperiod) simply because its share of GDP is so much smaller ( 3.5 to $5.2 \%$ in the case of private housing investment vs. 15.6 to $19.2 \%$ in the case of private plant and equipment investment).

We turn finally to the composition of household consumption. Data for the 1991-2001 period are shown in Table 4 (data for 2002 are not yet available as of this writing), and as can be seen from this table, "communication" (13.95\%) showed by far the most rapid growth during the 1991-2001 period (presumably because of the rapid diffusion of cell phones), followed by "health" (2.87\%), "restaurants and hotels" (2.42\%), "housing, electricity, gas and water supply" 
$(2.34 \%)$, and "recreation and culture" $(2.25 \%)$, while "clothing and footwear" $(-2.35 \%)$ and “education" (-1.32\%) declined (see column (1) of Table 4).

In terms of the contribution of each component to real household consumption growth, "housing, electricity, gas and water supply" made by far the largest contribution during the 1991-2001 period (37.57\%) because its growth rate was relatively high (2.34\%) and because its share of total household consumption was by far the highest (24.10\% in 2001) (see columns (2) and (3) of Table 4). The overwhelming contribution of housing-related expenditures was due primarily to the increase in the imputed rent on owner-occupied housing (imputed services of owner-occupied dwellings), whose average growth rate was $2.48 \%$, whose share of total household consumption was $17.07 \%$ in 2001 , and whose contribution to real household consumption growth was $28.03 \%$. Imputed rent on owner-occupied housing is likely to be mismeasured because it is not a market transaction but rather is imputed using various assumptions, and I doubt that it grew as rapidly as the official figures suggest during a period when land prices were declining steadily. Thus, the fact that imputed rent on owner-occupied housing was the single largest source of growth of household consumption during the 1991-2001 period, according to the official figures, suggests that there is considerable uncertainty about exactly how much consumption grew during this period.

"Communication" made the second largest contribution during the 1991-2001 period (21.29\%) even though its share of total household consumption was only $3.85 \%$ in 2001 because its growth rate was by far the highest during this period (13.95\%). "Recreation and culture" and "restaurants and hotels" made the third and fourth largest contributions during the 1991-2001 period (18.14\% and $11.34 \%$, respectively) because both their growth rates as well as their shares of total household consumption were relatively high $(2.25 \%$ and $12.05 \%$, respectively, in the case of "recreation and culture" and $2.42 \%$ and $7.06 \%$, respectively, in the case of "restaurants and hotels"). By contrast, the contribution of "clothing and footwear" was sizably negative during the 1991-2001 period (-10.49\%) because its growth rate was sizably negative $(-2.35 \%)$ and because its share of total household consumption was moderately high (5.18\% in 2001), and the contribution of "education" was also negative but negligible $(-2.08 \%)$. 
With the exception of housing-related expenditures, necessities such as "food and non-alcoholic beverages," "alcoholic beverages and tobacco," and "clothing and footwear" were the most stagnant and contributed the most to the stagnation of household consumption during the 1991-2001 period, whereas luxuries such as "communication," "recreation and culture," and "restaurants and hotels" showed the strongest growth and contributed the most to holding up household consumption during this period. Thus, somewhat surprisingly, consumption patterns became more affluent during the 1990s despite the stagnation of household incomes and wealth, suggesting that the decade-long recession was not severe enough to impoverish Japanese households. However, it could be that the increasing affluence of consumption patterns is attributable to an increase in income and wealth disparities among Japanese households, and if this explanation is the correct one, it implies that the poor became even poorer.

In any case, household consumption did not cause the decade-long recession in Japan during the 1990s and early 2000s (assuming that the growth rate of imputed rent on owner-occupied housing was not upward biased during this period). In fact, household consumption prevented the recession from becoming even worse and was the main contributor to economic growth during the 1990s and early 2000s, with housing-related expenditures, communication, and recreation and culture contributing the most. The main causes of the recession were the sharp declines in private fixed investment and, to a lesser extent, inventory investment. Note, however, that this conclusion must be regarded as tentative until a more rigorous analysis can be done.

Saito (2000) does a similar analysis for the earlier postwar period and finds that household consumption made the largest contribution to real GDP growth during the earlier postwar period as well but that its contribution (and also the contribution of government consumption) were not as large as they were after 1991. Thus, the role played by household (and government) consumption during the post-1991 period was large not only in absolute terms but also relative to the earlier postwar period. 


\section{The Causes of the Stagnation of Household Consumption}

In the previous section, we found that household consumption did not cause the decade-long recession during the 1990s and early 2000s, but it is nonetheless true that household consumption was relative stagnant during this period. In this section, we analyze the causes of the stagnation of household consumption during the 1990s and early 2000s.

Economic theory predicts that household consumption will be influenced by the following factors, among others:

(1) Household disposable income

(2) Household wealth

(3) Uncertainty about the future (for example, about income, employment, retirement, old-age pensions, etc.)

(4) Future prospects (for example, about income, employment, etc.)

These factors may have contributed to the stagnation of household consumption during the 1991-2002 period if:

(1) Household disposable income had declined or been stagnant

(2) Household wealth had declined

(3) Uncertainty about the future had increased

(4) Future prospects had deteriorated

during this period. We look at each of these factors in turn.

\section{(1) The Stagnation of Household Disposable Income}

The average annual real growth rate of household disposable income was only $0.50 \%$ during the 1991-2002 period, which is far less than the average annual real growth rate of household consumption during the same period $(1.35 \%)$. This suggests that the stagnation of 
household disposable income was a major cause of the stagnation of household consumption and that it would have caused household consumption to be even more stagnant had it not been for other factors operating in the opposite direction.

Figure 1 shows the annual real growth rates of household consumption and household disposable income during the 1991-2002 period, and as can be seen from this figure, the two are relatively close in most years (with the exception of 1996 and 2001). The growth rate of household consumption far exceeded the growth rate of household disposable income in both

years. It could be that the growth rate of household consumption was considerably higher than the growth rate of household disposable income in 1996 because the consumption tax was raised from 3\% to 5\% on April 1, 1996, and consumers accelerated purchases of goods and services to take advantage of the lower consumption tax. ${ }^{2}$

\section{(2) The Decline in Household Wealth}

Household wealth (net worth) declined during the 1991-2002 period as a whole, due largely to the sharp decline in land and equity prices, and the average annual real rate of decline of household wealth during this period was $0.84 \%$. Thus, it is quite possible that the stagnation of household consumption during this period was due at least partly to the decline in household wealth (a reverse wealth effect).

Figure 2 shows the annual real growth rates of household consumption and household wealth during the 1991-2002 period, and as can be seen from this figure, the two are relatively close in most years (with the exception of 1991-92 and 1999). The growth rate of household consumption exceeded that of household wealth in 1991-92 and conversely in 1999.

The relatively strong growth of household consumption in 1991 despite the relatively sharp decline in household wealth in that year can be explained by the relatively strong growth of household disposable income in that year. What cannot be explained is why household consumption increased so much in 1992, 1996, and 2001 even though the growth rates of both household disposable income and household wealth were relatively low in those years (and both were even negative in 2001). It thus appears that household disposable income and household 
wealth are not the only determinants of household consumption. For this reason, I turn now to other possible determinants of household consumption.

\section{(3) Increased Uncertainty about the Future}

If the stagnation of household consumption were due to increased uncertainty about the future, we would expect the household saving rate to have increased, but in fact it has declined steadily and sharply during the 1991-2002 period (except during the 1996-98 period)--from $15.1 \%$ in 1991 to $6.4 \%$ in 2002 in the case of the unadjusted rate and from $13.3 \%$ in 1991 to $5.4 \%$ in 2002 in the case of the adjusted rate, a decrease of more than 50\% in both cases (see Table 5)! ${ }^{3}$

4 This suggests that the stagnation of household consumption is not due to increased uncertainty about the future, except possibly during the 1996-98 period, when the household saving rate increased from $9.9 \%$ to $11.1 \%$ in the case of the unadjusted rate and from $8.5 \%$ to $9.6 \%$ in the case of the adjusted rate. It is not surprising to find that the household saving rate showed a temporary upturn during the 1996-98 period because it is during this period that a spate of bankruptcies (most notably the bankruptcies of Yamaichi Securities and Hokkaido Takushoku Bank in November 1997) occurred in the financial sector. These bankruptcies caused increased uncertainty not only about the health of the financial sector but also about the employment situation because the bankruptcies entailed large-scale layoffs of workers.

Additional verification of the importance of uncertainty about the future can be obtained from data on saving motives, etc., from the Public Opinion Survey on Financial Assets and Liabilities, conducted annually by the Central Council for Financial Services Information. As Table 6 shows, the proportion of respondents saving for illness and unforeseen emergencies has not shown a clear trend over time, and the proportion saving for peace of mind has increased only moderately over time, but the proportion of respondents saving for old age has increased sharply over time (from 50.5\% in 1991 to $60.4 \%$ in 2003). Moreover, as Table 7 shows, the proportion of under-60 respondents who are worried about old age has increased sharply over time, from $63.7 \%$ in 1992 to $87.9 \%$ in 2003, and the proportion of these respondents who are worried about old age because pensions and insurance are not adequate increased from $55.5 \%$ to $72.2 \%$ over the same 
time period, making it the reason that increased the most in importance. This is not surprising because Japan's public pension system has been periodically reformed to keep it solvent in the face of rapid population aging — with contribution rates being increased, benefit levels being reduced, and the pensionable age being increased over time.

In a related line of research, Horioka and Watanabe (1997) and Horioka, et al. (2000) calculate the amount of saving for each motive and find that the retirement and precautionary motives are by far the most important motives for saving and that they are far more important in Japan than they are in the United States. Similarly, Horioka, Murakami, and Kohara (2002) and Horioka, Kohara, and Murakami (2004) find that dissaving is the most common way in which the Japanese deal with unforeseen emergencies, which corroborates the importance of the precautionary motive as a motive for saving in Japan from the other side of the ledger.

A number of studies have analyzed the importance in Japan of precautionary saving arising from various types of uncertainty. For example, Ginama (1988), Ogawa (1991), Doi (2001, 2003, 2004), and Zhou (2003) analyze the importance of precautionary saving arising from income risk. Ginama (1988), Ogawa (1991), and Zhou (2003) find that precautionary saving arising from income risk is relatively unimportant except at the time of the first oil crisis and except for the self-employed and farmers, and Doi $(2003,2004)$ finds that it is of some importance in the case of salaried worker households but that employment risk is not important (but see also the next subsection). Murata (2003a, 2003b) looks at the importance of precautionary saving arising from uncertainty about overall economic conditions and from uncertainty about old-age pensions and finds that the former is not important but that the latter is. Nakagawa (1999) analyzes the importance of different types of uncertainty on the household saving rate in Japan by age and income and finds that different types of uncertainties are important for different age and income groups: he finds that income risk is important for the lowto middle-income, that employment risk is important for the middle-aged and aged low-income, that uncertainty about old-age pensions is important for the young, and that the risk of becoming bedridden is important for the aged. Finally, Saito and Shiratsuka (2003a, 2003b) analyze the impact of various types of uncertainty on the household saving rate and find that uncertainty 
about employment and price deflation and, to a lesser extent, overall uncertainty and uncertainty about income exert upward pressure on the household saving rate. ${ }^{5}$

Thus, the available evidence is not always consistent, but it suggests that precautionary saving arising from income risk or employment risk has generally not been all that important nor has it increased over time but that precautionary saving arising from uncertainty about old age in general and about old-age pensions in particular is important and has increased over time and hence that it may have contributed to the stagnation of household consumption during the 1991-2002 period.

\section{(4) The Deterioration of Future Prospects}

In the previous subsection, we discussed the impact of increased uncertainty concerning the future, but a closely related factor is the deterioration of future prospects. If household expectations concerning future incomes, future employment prospects, etc., deteriorate, this should cause them to reduce their current consumption. In addition to looking at the impact of income and employment uncertainty, Doi $(2001,2003,2004)$ also looks at the impact of the deterioration of income and employment prospects on the household saving rate in Japan and finds that reduced employment prospects have had a negative and significant impact on Japan's household saving rate but that the impact of reduced income prospects is marginal at best. Japan's unemployment rate has increased steadily throughout the 1990s, reaching its highest level ever (5.5\%) in August 2002 and remaining at or near this level ever since. Thus, Doi's finding that reduced employment prospects have induced Japanese households to save more and consume less is not at all surprising.

\section{(5) Other Factors}

Turning finally to other factors that may have influenced the level of household consumption, (1) deflationary expectations concerning consumer prices may have depressed household consumption because consumer prices have been falling since the mid-1990s (with the exception of 1997) and because price deflation means that the longer one waits, the cheaper one 
can buy a given item. By contrast, (2) near-zero interest rates may have depressed household saving and boosted household consumption to the extent that the interest elasticity of saving is positive, (3) the rapid aging of the population may also have boosted household consumption because the elderly typically finance their living expenses in large part by decumulating their previously accumulated savings, as a result of which their propensity to consume is typically higher than that of the working-age population, and (4) the introduction of a public long-term care insurance program in 2000 may have weakened the perceived need to save, thereby boosting consumption. Thus, there are factors working in both directions, and the factors that exert upward pressure on household consumption have presumably prevented the stagnation of household consumption from becoming worse than it already was.

\section{(6) Summary}

In sum, the evidence suggests that the stagnation of household disposable income and the decline in household wealth (the latter of which was due primarily to the collapse of land and equity prices) appear to have been the main causes of the stagnation of household consumption during the 1990s and early 2000s. Increased uncertainty about the future does not appear to have been a major cause of the stagnation of household consumption during the decade as a whole, but it does appear to have been of some importance during the 1996-98 period, and increased uncertainty about old age in general and about old-age pensions in particular may have contributed to the stagnation of household consumption during the period as a whole. Finally, the deterioration of future prospects and deflationary expectations concerning consumer prices may also have contributed to the stagnation of household consumption, whereas near-zero interest rates, the rapid aging of the population, and the introduction of a public long-term care system may have worked in the opposite direction.

\section{Conclusion}

In this paper, I considered the extent to which the stagnation of household consumption is responsible for the decade-long recession in Japan during the 1990s and the early 2000s and the 
reasons for the stagnation of household consumption during this period and find that the stagnation of private investment (and inventory investment) rather than that of household consumption was the major cause of the decade-long recession, that household consumption was nonetheless relatively stagnant during this decade, and that the stagnation of household consumption was due primarily to the stagnation of household disposable income, the decline in household wealth (which in turn was due primarily to the collapse of land and equity prices), and to a lesser extent, increased uncertainty about the future (especially about old age in general and old-age pensions in particular), the deterioration of future prospects, and deflationary expectations concerning consumer prices.

Turning finally to policy recommendations, my findings suggest that the best way to bring the Japanese economy out of recession would be to stimulate private investment in housing and plant and equipment as well as household consumption, and in my opinion, the best way of doing so would be to introduce temporary and targeted tax breaks for housing and plant and equipment investment, household consumption, etc. There are those who oppose tax breaks of any kind because Japan already has the highest government debt-to-GDP ratio of any major industrialized nation in the world, but I favor temporary and targeted tax breaks for the following reasons: (1) the Japanese economy is unlikely to recover fully without further stimulus, and as long as the economy does not recover, tax revenues will decline further, causing the government debt to increase further, (2) temporary and targeted tax breaks will increase the government debt far less than would more permanent and/or broad-based tax cuts, and (3) the tax breaks will be more effective if they are temporary because temporary tax breaks will induce firms and consumers to accelerate their purchases of the goods and services being targeted in order to take advantage of the tax breaks before they expire. Two specific proposals I have are to introduce a temporary investment tax credit for investment in plant and equipment and to temporarily reduce or abolish the consumption tax (currently 5\%). A tax break for housing investment is already in place but is scheduled to be phased out so another option would be to extend or expand this tax break temporarily.

My analysis suggests that an alternative way of stimulating household consumption tax 
would be to reduce uncertainty about the future, especially about old age in general and about old-age pensions in particular--for example by fundamentally reforming the public old-age pension system to make it solvent as well as equitable. A major reform of the public pension system is scheduled for 2004 so what better time could there be for implementing a fundamental reform of the public old-age pension system? If increases in public pension contributions are needed to keep the system solvent, they should be collected in a way that is equitable to all cohorts, and that means collecting more from those who currently stand to get back more than they put in (namely, those born in 1962 or later) (see Hatta and Oguchi (1999) and Horioka (2001)). The current proposal to reduce the earnings replacement rate to $50 \%$ and to raise the contribution rate to $18.5 \%$ will probably not be enough to make the system solvent, but more importantly, it does not pay any heed to the important issue of intergenerational equity.

In 2003, there was a sharp increase not only in the proportion of people saving for old age but also in the proportion of people who are worried about old age because of the inadequacy of pensions and insurance (see Tables 6-7). Thus, there is an urgent need to allay people's fears about public pensions, and doing so will have the added benefit of stimulating household consumption.

\section{References}

Bank of Japan Research Department (1998), "Saikin no Kojin Shouhi Doukou ni tsuite (On Recent Trends in Personal Consumption)," Nippon Ginkou Chousa Geppou (Bank of Japan Monthly Research Report) (May), pp. 111-139 (in Japanese).

Doi, Takero (2001), “Chochiku-ritsu Kansuu ni motozuku Yobi-teki Chochiku Kasetsu no Kenshou (A Test of the Precautionary Saving Hypothesis using a Saving Rate Function)," ESRI Discussion Paper no. 1, Economic and Social Research Institute, Cabinet Office, Government of Japan (in Japanese).

Doi, Takero (2003), "Por que ahorran los hogares japoneses? Caidas en la renta y situacion del 
Mercado de trabajo (Precautionary saving and employment risk in the 1990s)," Informacion Comercial Espanola, no. 807 (October), pp. 57-81 (in Spanish).

Doi, Takero (2004), "Precautionary Saving and Employment Risk in the 1990s," ESRI Discussion Paper, Economic and Social Research Institute, Cabinet Office, Government of Japan.

Ginama, Isamu (1988), Estimation of Precautionary Savings in the U.S. and Japan, unpublished Ph.D. dissertation, University of California, San Diego.

Hatta, Tatsuo, and Oguchi, Noriyoshi (1999), Nenkin Kaikaku-ron: Tsumitate Houshiki e Ikou seyo (The Theory of Pensions: Switch to a Funded System). Tokyo: Nihon Keizai Shinbunsha (in Japanese).

Horioka, Charles Yuji (2001), “Japan's Public Pension System in the Twenty-First Century," in Magnus Blomstrom, Byron Gangnes, and Sumner La Croix, eds., Japan's New Economy: Continuity and Change in the Twenty-First Century (New York: Oxford University Press Inc.), pp. 99-119.

Horioka, Charles Yuji; Fujisaki, Hideki; Watanabe, Wako; and Kouno, Takatsugu (2000), “Are Americans More Altruistic than the Japanese? A U.S.-Japan Comparison of Saving and Bequest Motives," International Economic Journal, vol. 14, no. 1 (Spring), pp. 1-31.

Horioka, Charles Yuji; Kohara, Miki; and Murakami, Akane (2004), "Defure Jidai ni okeru Nihonjin no Risuku Taisho-hou (The Risk Coping Mechanisms of the Japanese in a Deflationary Age)," in Kiyoshi Ohta, Yoshio Higuchi, and the Institute for Research on Household Economics, eds., Defure Jidai no Josei no Kurashi to Hatarakikata (The Lives and Careers of Women in an Deflationary Age) (Tokyo: Nihon Keizai Shinbunsha), forthcoming (in Japanese). 
Horioka, Charles Yuji; Murakami, Akane; and Kohara, Miki (2002), "How Do the Japanese Cope with Risk?" Seoul Journal of Economics, vol. 15, no. 1 (Spring), pp. 1-30.

Horioka, Charles Yuji, and Watanabe, Wako (1997), "Why Do People Save? A Micro-Analysis of Motives for Household Saving in Japan," Economic Journal, vol. 107, no. 442 (May), pp. $537-552$.

Kin'yuu Kouhou Chuuou Iinkai (The Central Council for Financial Services Information), ed., Kakei no Kin'yuu Shisan ni kansuru Seron Chousa (Public Opinion Survey on Household Financial Assets and Liabilities), 2003 edition. Tokyo: Kin'yuu Kouhou Chuuou Iinkai (The Central Council for Financial Services Information).

Murata, Keiko (2003a), "Mikuro De-ta ni yoru Kakei Koudou Bunseki: Shourai Fuan to Yobi-teki Chochiku (An Analysis of Household Behavior based on Micro Data: Uncertainty about the Future and Precautionary Saving)," Kinkyuu Kenkyuu (Institute for Monetary and Economic Studies, Bank of Japan), vol. 22, no. 3 (September), pp. 23-58 (in Japanese).

Murata, Keiko (2003b), "Precautionary Savings and Income Uncertainty: Evidence from Japanese Micro Data," IMES Discussion Paper No. 2003-E-9, Institute for Monetary and Economic Studies, Bank of Japan.

Naikakufu Keizai Shakai Sougou Kenkyuusho (Economic and Social Research Institute, Cabinet Office, Government of Japan) (2004), Kokumin Keizai Keisan Nenpou (Annual Report on National Accounts), 2004 edition (and the 2003 edition of the same). Tokyo: Dokuritsu Gyousei Houjin Kokuritsu Insatsu-kyoku (Government Printing Bureau).

Nakagawa, Shinobu (1999), "90-nen-dai-irigo mo Nihon no Kakei Chochiku-ritsu ha Naze Takai-ka? (Why Is Japan's Household Saving Rate High Even After Entering the 1990s?),” 
Nippon Ginkou Chousa Geppou (Bank of Japan Monthly Research Report) (April), pp. 69-101 (in Japanese).

Ogawa, Kazuo (1991), "Shotoku Risuku to Yobi-teki Chochiku (Income Risk and Precautionary Saving)," Keizai Kenkyuu, vol. 42, no. 2 (April), pp. 139-152 (in Japanese).

Saito, Makoto, and Shiratsuka, Shigenori (2003a), "Precautionary Motives versus Waiting Options: Evidence from Aggregate Household Saving in Japan," IMES Discussion Paper No. 2003-E-2, Institute for Monetary and Economic Studies, Bank of Japan.

Saito, Makoto, and Shiratsuka, Shigenori (2003b), "Yobi-teki Douki to Machi no Opushon: Wagakuni no Makuro Kakei Chochiku De-ta ni yoru Kenshou (Precautionary Motives versus Waiting Options: A Test based on Japanese Aggregate Household Saving Data)," Kinyuu Kenkhyuu (Institute for Monetary and Economic Studies, Bank of Japan), vol. 22, no. 3 (September), pp. 1-18 (in Japanese).

Saito, Mitsuo (2000), The Japanese Economy (Economic Ideas Leading to the $21^{\text {st }}$ Century, vol. 1). River Edge, N.J.: World Scientific Publishing Co., Inc.

Zhou, Yanfei (2003), "Precautionary Saving and Earnings Uncertainty in Japan: A Household-level Analysis," Journal of the Japanese and International Economies, vol. 17, no. 2 (June), pp. 192-212. 
Table 1: Average Annual Real Growth Rate of Each Component of GDP, 1991-2002

\begin{tabular}{lccc}
\hline \multicolumn{1}{c}{ Component of GDP } & Average Annual Real Growth Rate (percent) \\
\cline { 2 - 4 } & $1991-2002$ & $1991-1997$ & $1997-2002$ \\
\hline Final consumption expenditure of households & 1.35 & 1.94 & 0.65 \\
Final consumption expenditure of private non-profit & & & \\
institutions serving households & 4.55 & 4.64 & 4.44 \\
Government final consumption expenditure & 3.07 & 2.82 & 3.38 \\
Private gross domestic fixed capital formation & -1.19 & -0.96 & -1.47 \\
Housing & $(-2.58)$ & $(-0.72)$ & $(-4.76)$ \\
Plant and equipment & $(-0.84)$ & $(-1.02)$ & $(-0.63)$ \\
Public gross domestic fixed capital formation & 0.71 & 4.00 & -3.09 \\
Dwellings & $(-0.23)$ & $(6.19)$ & $(-7.42)$ \\
Plant and equipment & $(0.16)$ & $(4.02)$ & $(-4.28)$ \\
General government & $(0.91)$ & $(3.89)$ & $(-2.54)$ \\
Changes in inventories (inventory investment) & -193.06 & 2.18 & -183.19 \\
Private sectors & $(-192.66)$ & $(0.24)$ & $(-184.32)$ \\
Public sectors & $(-170.10)$ & $(\mathrm{na})$ & $(-57.31)$ \\
Net exports of goods and services & 4.55 & 3.09 & 6.32 \\
Exports of goods and services & $(3.74)$ & $(4.82)$ & $(2.45)$ \\
Imports of goods and services & $(3.52)$ & $(5.25)$ & $(1.49)$ \\
\hline Gross domestic expenditure (product) & 1.03 & 1.58 & 0.36 \\
\hline
\end{tabular}

Note: The average annual real growth rate of component $\mathrm{X}$ between year $\mathrm{t} 1$ and year $\mathrm{t} 2$ was calculated as $[(\mathrm{X}(\mathrm{t} 2)-\mathrm{X}(\mathrm{t} 1)) * *(1 /(\mathrm{t} 2-\mathrm{t} 1))-1] * 100$.

Source: Naikakufu Keizai Shakai Sougou Kenkyuusho (Economic and Social Research Institute, Cabinet Office, Government of Japan), ed., Kokumin Keizai Keisan Nenpou (Annual Report on National Accounts), 2004 edition (Tokyo: Dokuritsu Gyousei Houjin Kokuritsu Insatsu-kyoku 
Table 2: Contribution to Real GDP Growth of Each Component of GDP, 1991-2002

\begin{tabular}{lccc}
\hline \multicolumn{1}{c}{ Component of GDP } & \multicolumn{3}{c}{ Contribution to Real GDP (percent) } \\
\cline { 2 - 4 } & $1991-2002$ & $1991-1997$ & $1997-2002$ \\
\hline Final consumption expenditure of households & 70.30 & 64.95 & 96.70 \\
Final consumption expenditure of private non-profit & & & \\
institutions serving households & 4.34 & 2.58 & 13.00 \\
Government final consumption expenditure & 44.60 & 24.65 & 143.02 \\
Private gross domestic fixed capital formation & -25.30 & -13.82 & -81.94 \\
Housing & $(-10.95)$ & $(-2.25)$ & $(-53.85)$ \\
Plant and equipment & $(-14.35)$ & $(-11.56)$ & $(-28.09)$ \\
Public gross domestic fixed capital formation & 4.40 & 17.26 & -59.00 \\
Dwellings & $(-0.05)$ & $(0.97)$ & $(-5.04)$ \\
Plant and equipment & $(0.21)$ & $(3.86)$ & $(-17.77)$ \\
General government & $(4.24)$ & $(12.43)$ & $(-36.19)$ \\
Changes in inventories (inventory investment) & -7.54 & 0.86 & -49.01 \\
Private sectors & $(-7.81)$ & $(0.10)$ & $(-46.83)$ \\
Public sectors & $(0.27)$ & $(0.77)$ & $(-2.19)$ \\
Net exports of goods and services & 9.20 & 3.51 & 37.24 \\
Exports of goods and services & $(35.54)$ & $(28.08)$ & $(72.33)$ \\
Imports of goods and services & $(26.34)$ & $(24.57)$ & $(35.09)$ \\
\hline Gross domestic expenditure (product) & 100.00 & 100.00 & 100.00 \\
\hline
\end{tabular}

Note: The contribution of each component to real GDP growth is calculated as the ratio of the real change in that component over the period in question to the real change in GDP over the same period.

Source: The same as Table 1. 
Table 3: Composition of GDP, 1991-2002

\begin{tabular}{lrrr}
\hline & \multicolumn{3}{c}{ Share of GDP (percent) } \\
\cline { 2 - 4 } & 1991 & 1997 & 2002 \\
\hline Final consumption expenditure of households & 52.60 & 53.71 & 54.48 \\
Final consumption expenditure of private non-profit & & & \\
institutions serving households & 0.82 & 0.98 & 1.19 \\
Government final consumption expenditure & 13.43 & 14.44 & 16.74 \\
Private gross domestic fixed capital formation & 24.38 & 20.94 & 19.10 \\
Housing & $(5.21)$ & $(4.54)$ & $(3.49)$ \\
Plant and equipment & $(19.17)$ & $(16.40)$ & $(15.61)$ \\
Public gross domestic fixed capital formation & 6.43 & 7.40 & 6.21 \\
Dwellings & $(0.22)$ & $(0.29)$ & $(0.19)$ \\
Plant and equipment & $(1.43)$ & $(1.65)$ & $(1.30)$ \\
General government & $(4.78)$ & $(5.47)$ & $(4.72)$ \\
Changes in inventories (inventory investment) & 0.62 & 0.64 & -0.25 \\
Private sectors & $(0.65)$ & $(0.60)$ & $(-0.25)$ \\
Public sectors & $(-0.03)$ & $(0.04)$ & $(0.00)$ \\
Net exports of goods and services & 1.73 & 1.89 & 2.52 \\
Exports of goods and services & $(8.49)$ & $(10.25)$ & $(11.36)$ \\
Imports of goods and services & $(6.76)$ & $(8.36)$ & $(8.84)$ \\
\hline Gross domestic expenditure (product) & 100.00 & 100.00 & 100.00 \\
\hline
\end{tabular}

Source: The same as Table 1. 
Table 4: Average Annual Real Growth Rate, Share, and Contribution to Household Consumption Growth of Each Component of Household Consumption Classified by Purpose of Expenditure, 1991-2001

\begin{tabular}{lcrr}
\hline \multicolumn{1}{c}{ Purpose of expenditure } & $\begin{array}{c}\text { Average } \\
\text { Annual Real } \\
\text { Growth Rate, } \\
1991-2001 \\
\text { (percent) }\end{array}$ & $\begin{array}{c}\text { Share of } \\
\text { Household } \\
\text { Consumption } \\
\text { in 2001 } \\
\text { (percent) }\end{array}$ & $\begin{array}{c}\text { Contribution } \\
\text { to Real Household } \\
\text { Consumption } \\
\text { Growth, 1991-2001 } \\
\text { (percent) }\end{array}$ \\
\hline Food and non-alcoholic beverages & 0.13 & 14.36 & 1.41 \\
Alcoholic beverages and tobacco & 0.46 & 2.95 & 1.00 \\
Clothing and footwear & -2.35 & 5.18 & -10.49 \\
Housing, electricity, gas and water supply & 2.34 & 24.10 & 37.57 \\
$\quad$ Imputed service of owner- & & & $(28.03$ ) \\
$\quad$ occupied dwellings & $(2.48)$ & $(17.07)$ & 5.14 \\
Furnishings, household equipment and & & & 6.75 \\
$\quad$ household services & 1.46 & 5.04 & 5.12 \\
Health & 2.87 & 3.63 & 21.19 \\
Transport & 0.69 & 10.25 & 18.14 \\
Communication & 13.95 & 3.85 & -2.08 \\
Recreation and culture & 2.25 & 12.05 & 11.34 \\
Education & -1.32 & 1.93 & 4.90 \\
Restaurants and hotels & 2.42 & 7.06 & 100.00 \\
Miscellaneous goods and services & 0.70 & 9.60 & \\
\hline Domestic final consumption expenditure & & & \\
$\quad$ of households & 1.43 & 100.00 & \\
\hline
\end{tabular}

Note: See the notes to Tables 1 and 2 for a description of the calculation method.

Source: Naikakufu Keizai Shakai Sougou Kenkyuusho (Economic and Social Research Institute, Cabinet Office, Government of Japan), ed., Kokumin Keizai Keisan Nenpou (Annual Report on National Accounts), 2003 edition (Tokyo: Zaimushou Insatsu-kyoku (Ministry of Finance Printing Bureau), 2003). 
Table 5: Trends in the Household Saving Rate, 1990-2002

\begin{tabular}{rrr}
\hline \multicolumn{1}{c}{ Calendar } & & \\
Year & Unadjusted Household Saving Rate & Adjusted Household Saving Rate \\
\hline 1990 & 13.9 & 12.3 \\
1991 & 15.1 & 13.3 \\
1992 & 14.2 & 12.5 \\
1993 & 13.7 & 12.0 \\
1994 & 12.6 & 11.1 \\
1995 & 11.9 & 10.4 \\
1996 & 9.9 & 8.5 \\
1997 & 10.0 & 8.6 \\
1998 & 11.1 & 9.6 \\
1999 & 10.7 & 9.2 \\
2000 & 9.6 & 8.2 \\
2001 & 6.7 & 5.6 \\
2002 & 6.4 & 5.4 \\
\hline
\end{tabular}

Note: See footnote 3 for the difference between the unadjusted and adjusted rates.

Source: The same as Table 1. 
Table 6: The Proportion of Respondents Saving for Each Motive, 1984-2003

\begin{tabular}{|c|c|c|c|}
\hline \multirow[b]{2}{*}{$\begin{array}{c}\text { Calendar } \\
\text { Year }\end{array}$} & \multicolumn{3}{|c|}{ Saving motive } \\
\hline & $\begin{array}{l}\text { Illness and } \\
\text { unforeseen } \\
\text { emergencies }\end{array}$ & Peace of mind & Old age \\
\hline 1984 & 75.0 & 25.7 & 42.1 \\
\hline 1985 & 77.2 & 26.4 & 42.5 \\
\hline 1986 & 75.0 & 25.3 & 42.5 \\
\hline 1987 & 76.4 & 26.1 & 46.1 \\
\hline 1988 & 77.1 & 28.0 & 50.2 \\
\hline 1989 & 80.5 & 28.7 & 51.5 \\
\hline 1990 & 74.3 & 25.7 & 52.4 \\
\hline 1991 & 73.3 & 23.7 & 50.5 \\
\hline 1992 & 68.3 & 23.0 & 48.2 \\
\hline 1993 & 70.9 & 23.5 & 50.1 \\
\hline 1994 & 69.4 & 24.2 & 51.6 \\
\hline 1995 & 71.2 & 25.2 & 52.9 \\
\hline 1996 & 69.7 & 25.9 & 53.9 \\
\hline 1997 & 69.1 & 24.9 & 53.2 \\
\hline 1998 & 73.3 & 24.5 & 55.3 \\
\hline 1999 & 71.9 & 27.5 & 56.7 \\
\hline 2000 & 67.5 & 27.1 & 55.9 \\
\hline 2001 & 69.4 & 26.2 & 58.6 \\
\hline 2002 & 69.1 & 26.9 & 56.9 \\
\hline 2003 & 73.3 & 25.4 & 60.4 \\
\hline
\end{tabular}

Source: Kin'yuu Kouhou Chuuou Iinkai (The Central Council for Financial Services Information), ed., Kakei no Kin'yuu Shisan ni kansuru Seron Chousa (Public Opinion Survey on Household Financial Assets and Liabilities), 2003 edition (Tokyo: Kin'yuu Kouhou Chuuou Iinkai (The Central Council for Financial Services Information), 2003). 
Table 7: The Proportion of Respondents Who Are Worried about Old Age, 1984-2003

\begin{tabular}{lrr}
\hline $\begin{array}{c}\text { Calendar } \\
\text { Year }\end{array}$ & $\begin{array}{c}\text { Proportion of under-60 respondents } \\
\text { who are worried about old age }\end{array}$ & $\begin{array}{c}\text { Proportion of under-60 respondents } \\
\text { whe } \begin{array}{c}\text { arried about old age because pensions and } \\
\text { insurance are not adequate }\end{array}\end{array}$ \\
\hline 1984 & na & 49.1 \\
1985 & na & 60.6 \\
1986 & na & 64.5 \\
1987 & na & 63.5 \\
1988 & na & 69.6 \\
1989 & na & 71.0 \\
1990 & na & 68.0 \\
1991 & na & 60.8 \\
1992 & 63.7 & 55.5 \\
1993 & 62.0 & 59.5 \\
1994 & 69.9 & 59.1 \\
1995 & 71.6 & 56.9 \\
1996 & 71.3 & 59.0 \\
1997 & 78.8 & 63.1 \\
1998 & 85.5 & 67.1 \\
1999 & 84.1 & 66.9 \\
2000 & 84.7 & 68.1 \\
2001 & 84.3 & 66.5 \\
2002 & 86.6 & 66.7 \\
2003 & 87.9 & 72.2 \\
\hline
\end{tabular}

Note: The denominator in the right-hand column is under-60 respondents who are worried about old age.

Source: The same as Table 6. 
Figure 1: Growth Rates of Household Consumption and Household Disposable Income, 1991-2002

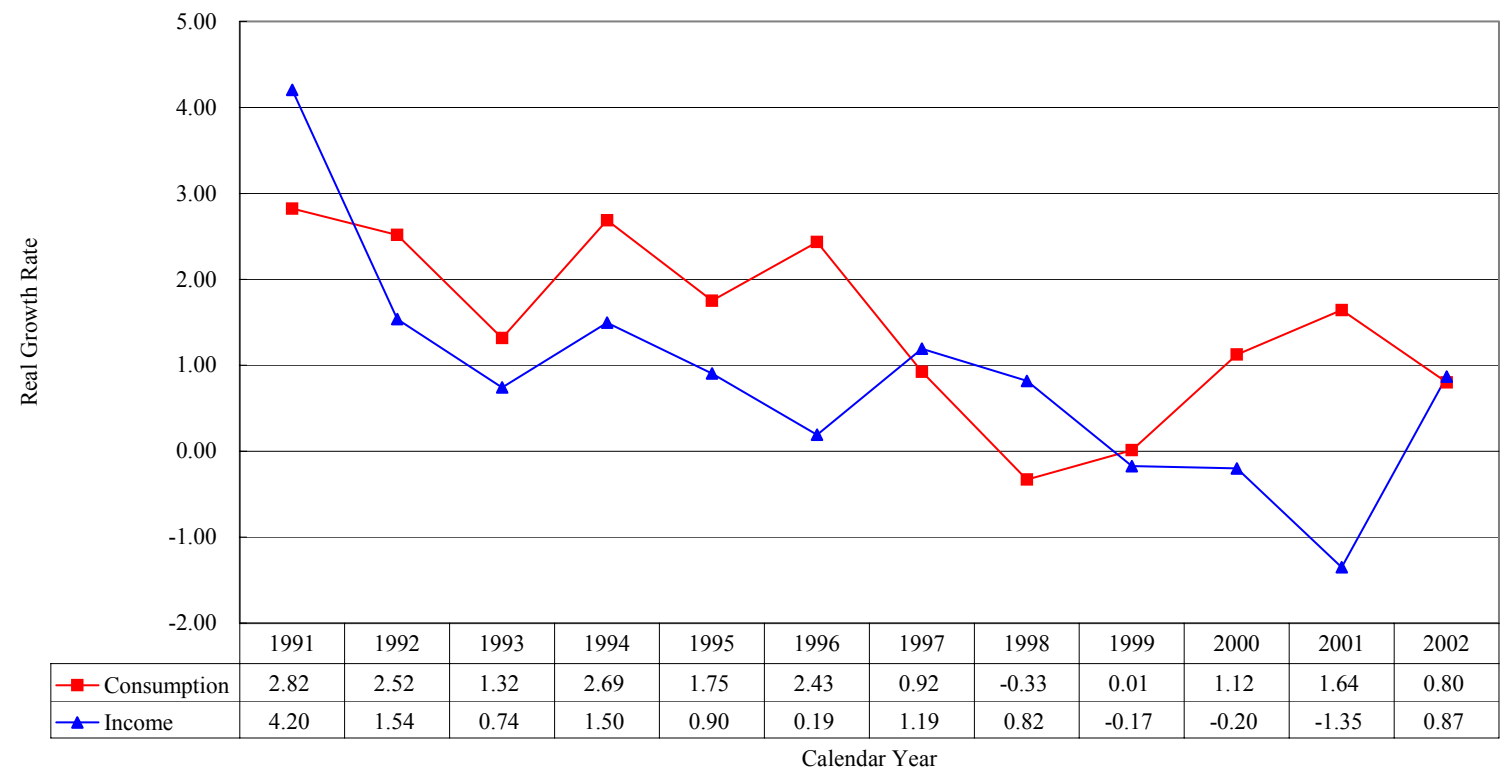

Notes: The line marked "Consumption" shows the annual real growth rate of the final consumption expenditure of households, while the line marked "Income" shows the annual real growth rate of household disposable income. Household disposable income was deflated using the price deflator for the final consumption expenditure of households.

Source: The same as Table 1. 


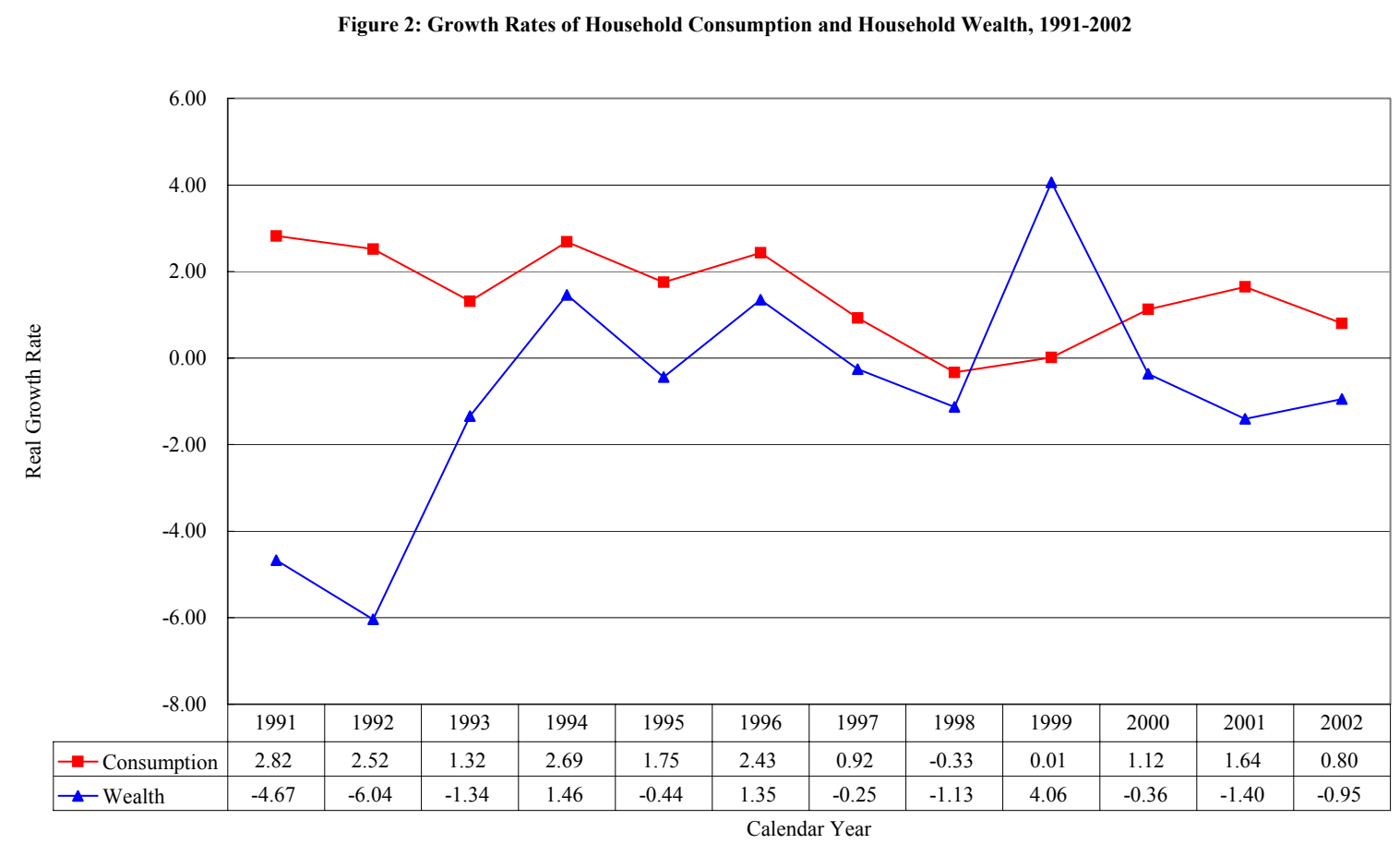

Notes: The line marked "Consumption" shows the annual real growth rate of the final consumption expenditure of households, while the line marked "Wealth" shows the annual real growth rate of household wealth (net worth) during the calendar year in question. Household wealth was deflated using the year-end price deflator for the final consumption expenditure of households, where the year-end price deflator was calculated by averaging the price deflator for the fourth quarter of the calendar year in question and that for the first quarter of the following calendar year.

Source: The same as Table 1. 


\section{Endnotes}

${ }^{1}$ This conclusion ignores second- and higher-order effects. For example, the stagnation of consumption might have induced firms to cut back on their investment spending. I am indebted to Keunkwan Ryu for this point.

${ }^{2}$ The fact that the real growth rate of household consumption relative to the same quarter of the previous year was higher in the first quarter of 1996 than it was in subsequent quarters of 1996 $(3.3 \%$ vs. $2.5 \%, 1.7 \%, 2.3 \%)$ corroborates this hypothesis.

${ }^{3}$ The difference between the two rates is that the latter includes "social transfers in kind, receivable" in the denominator whereas the former does not. "Social transfers in kind, receivable" are defined as the sum of "social benefits in kind" (the insurance-financed portion of medical and long-term care services) and "transfers of individual non-market goods and services" (government consumption that is attributable to individual households such as government-provided school textbooks).

${ }^{4}$ It is, of course, possible that households were not able to save more despite their desire to do so because of declining incomes and wealth.

${ }^{5}$ Saito and Shiratsuka (2003a, 2003b) distinguish between precautionary saving (which depends on the magnitude of risks) and saving as a waiting option (which depends on how long it takes for uncertainties about the future to be resolved). They find that precautionary saving has been more important since the 1980s but that there is some evidence of saving as a waiting option in the 1990s. 


\section{CESifo Working Paper Series}

(for full list see www.cesifo.de)

1066 Christian Keuschnigg, Public Policy and Venture Capital Backed Innovation, October 2003

1067 Thomas von Ungern-Sternberg, State Intervention on the Market for Natural Damage Insurance in Europe, October 2003

1068 Mark V. Pauly, Time, Risk, Precommitment, and Adverse Selection in Competitive Insurance Markets, October 2003

1069 Wolfgang Ochel, Decentralising Wage Bargaining in Germany - A Way to Increase Employment?, November 2003

1070 Jay Pil Choi, Patent Pools and Cross-Licensing in the Shadow of Patent Litigation, November 2003

1071 Martin Peitz and Patrick Waelbroeck, Piracy of Digital Products: A Critical Review of the Economics Literature, November 2003

1072 George Economides, Jim Malley, Apostolis Philippopoulos, and Ulrich Woitek, Electoral Uncertainty, Fiscal Policies \& Growth: Theory and Evidence from Germany, the UK and the US, November 2003

1073 Robert S. Chirinko and Julie Ann Elston, Finance, Control, and Profitability: The Influence of German Banks, November 2003

1074 Wolfgang Eggert and Martin Kolmar, The Taxation of Financial Capital under Asymmetric Information and the Tax-Competition Paradox, November 2003

1075 Amihai Glazer, Vesa Kanniainen, and Panu Poutvaara, Income Taxes, Property Values, and Migration, November 2003

1076 Jonas Agell, Why are Small Firms Different? Managers' Views, November 2003

1077 Rafael Lalive, Social Interactions in Unemployment, November 2003

1078 Jean Pisani-Ferry, The Surprising French Employment Performance: What Lessons?, November 2003

1079 Josef Falkinger, Attention, Economies, November 2003

1080 Andreas Haufler and Michael Pflüger, Market Structure and the Taxation of International Trade, November 2003

1081 Jonas Agell and Helge Bennmarker, Endogenous Wage Rigidity, November 2003 
1082 Fwu-Ranq Chang, On the Elasticities of Harvesting Rules, November 2003

1083 Lars P. Feld and Gebhard Kirchgässner, The Role of Direct Democracy in the European Union, November 2003

1084 Helge Berger, Jakob de Haan and Robert Inklaar, Restructuring the ECB, November 2003

1085 Lorenzo Forni and Raffaela Giordano, Employment in the Public Sector, November 2003

1086 Ann-Sofie Kolm and Birthe Larsen, Wages, Unemployment, and the Underground Economy, November 2003

1087 Lars P. Feld, Gebhard Kirchgässner, and Christoph A. Schaltegger, Decentralized Taxation and the Size of Government: Evidence from Swiss State and Local Governments, November 2003

1088 Arno Riedl and Frans van Winden, Input Versus Output Taxation in an Experimental International Economy, November 2003

1089 Nikolas Müller-Plantenberg, Japan’s Imbalance of Payments, November 2003

1090 Jan K. Brueckner, Transport Subsidies, System Choice, and Urban Sprawl, November 2003

1091 Herwig Immervoll and Cathal O'Donoghue, Employment Transitions in 13 European Countries. Levels, Distributions and Determining Factors of Net Replacement Rates, November 2003

1092 Nabil I. Al-Najjar, Luca Anderlini \& Leonardo Felli, Undescribable Events, November 2003

1093 Jakob de Haan, Helge Berger and David-Jan Jansen, The End of the Stability and Growth Pact?, December 2003

1094 Christian Keuschnigg and Soren Bo Nielsen, Taxes and Venture Capital Support, December 2003

1095 Josse Delfgaauw and Robert Dur, From Public Monopsony to Competitive Market. More Efficiency but Higher Prices, December 2003

1096 Clemens Fuest and Thomas Hemmelgarn, Corporate Tax Policy, Foreign Firm Ownership and Thin Capitalization, December 2003

1097 Laszlo Goerke, Tax Progressivity and Tax Evasion, December 2003

1098 Luis H. B. Braido, Insurance and Incentives in Sharecropping, December 2003 
1099 Josse Delfgaauw and Robert Dur, Signaling and Screening of Workers' Motivation, December 2003

1100 Ilko Naaborg, Bert Scholtens, Jakob de Haan, Hanneke Bol and Ralph de Haas, How Important are Foreign Banks in the Financial Development of European Transition Countries?, December 2003

1101 Lawrence M. Kahn, Sports League Expansion and Economic Efficiency: Monopoly Can Enhance Consumer Welfare, December 2003

1102 Laszlo Goerke and Wolfgang Eggert, Fiscal Policy, Economic Integration and Unemployment, December 2003

1103 Nzinga Broussard, Ralph Chami and Gregory D. Hess, (Why) Do Self-Employed Parents Have More Children?, December 2003

1104 Christian Schultz, Information, Polarization and Delegation in Democracy, December 2003

1105 Daniel Haile, Abdolkarim Sadrieh and Harrie A. A. Verbon, Self-Serving Dictators and Economic Growth, December 2003

1106 Panu Poutvaara and Tuomas Takalo, Candidate Quality, December 2003

1107 Peter Friedrich, Joanna Gwiazda and Chang Woon Nam, Development of Local Public Finance in Europe, December 2003

1108 Silke Uebelmesser, Harmonisation of Old-Age Security Within the European Union, December 2003

1109 Stephen Nickell, Employment and Taxes, December 2003

1110 Stephan Sauer and Jan-Egbert Sturm, Using Taylor Rules to Understand ECB Monetary Policy, December 2003

1111 Sascha O. Becker and Mathias Hoffmann, Intra-and International Risk-Sharing in the Short Run and the Long Run, December 2003

1112 George W. Evans and Seppo Honkapohja, The E-Correspondence Principle, January 2004

1113 Volker Nitsch, Have a Break, Have a ... National Currency: When Do Monetary Unions Fall Apart?, January 2004

1114 Panu Poutvaara, Educating Europe, January 2004

1115 Torsten Persson, Gerard Roland, and Guido Tabellini, How Do Electoral Rules Shape Party Structures, Government Coalitions, and Economic Policies? January 2004

1116 Florian Baumann, Volker Meier, and Martin Werding, Transferable Ageing Provisions in Individual Health Insurance Contracts, January 2004 
1117 Gianmarco I.P. Ottaviano and Giovanni Peri, The Economic Value of Cultural Diversity: Evidence from US Cities, January 2004

1118 Thorvaldur Gylfason, Monetary and Fiscal Management, Finance, and Growth, January 2004

1119 Hans Degryse and Steven Ongena, The Impact of Competition on Bank Orientation and Specialization, January 2004

1120 Piotr Wdowinski, Determinants of Country Beta Risk in Poland, January 2004

1121 Margarita Katsimi and Thomas Moutos, Inequality and Redistribution via the Public Provision of Private Goods, January 2004

1122 Martin Peitz and Patrick Waelbroeck, The Effect of Internet Piracy on CD Sales: CrossSection Evidence, January 2004

1123 Ansgar Belke and Friedrich Schneider, Privatization in Austria: Some Theoretical Reasons and First Results About the Privatization Proceeds, January 2004

1124 Chang Woon Nam and Doina Maria Radulescu, Does Debt Maturity Matter for Investment Decisions?, February 2004

1125 Tomer Blumkin and Efraim Sadka, Minimum Wage with Optimal Income Taxation, February 2004

1126 David Parker, The UK's Privatisation Experiment: The Passage of Time Permits a Sober Assessment, February 2004

1127 Henrik Christoffersen and Martin Paldam, Privatization in Denmark, 1980-2002, February 2004

1128 Gregory S. Amacher, Erkki Koskela and Markku Ollikainen, Deforestation, Production Intensity and Land Use under Insecure Property Rights, February 2004

1129 Yin-Wong Cheung, Javier Gardeazabal, and Jesús Vázquez, Exchange Rate Dynamics: Where is the Saddle Path?, February 2004

1130 Alberto Alesina and Guido Tabellini, Bureaucrats or Politicians?, February 2004

1131 Gregory S. Amacher, Erkki Koskela, and Markku Ollikainen, Socially Optimal Royalty Design and Illegal Logging under Alternative Penalty Schemes, February 2004

1132 David M. Newbery, Privatising Network Industries, February 2004

1133 Charles Yuji Horioka, The Stagnation of Household Consumption in Japan, February 2004 